\title{
AN ANALYSIS ON STUDENTS' MISTAKES IN WRITING A RECOUNT TEXT (A CASE STUDY ON EIGHTH-GRADE STUDENTS OF MTS AL-AMIN NGETOS, NGANJUK)
}

\author{
Puput Zuli Ekorini ${ }^{1 凶}$ \\ ${ }^{1,}$ Pendidikan Bahasa Inggris, STKIP PGRI Nganjuk, Jl. Abdul Rahman Saleh No. 21 Nganjuk, 64411. \\ $\bigotimes_{e-m a i l: p u p u t z u l i @ s t k i p n g a n j u k . a c . i d}$
}

\begin{abstract}
This study was conducted to analyze the students' mistakes in writing a recount text. The subject of this research was the eighth-grade students of Mts Al-Amin Ngetos, Nganjuk which was consisted of 38 students. The researcher needs to analyze the students' mistakes in writing a recount text because writing is one of the four crucial skills to master English. In learning English at school, students also learn how to write a text and organize their ideas into a proper text. In getting the data, the researcher applied class evaluation research using purposive sampling technique which the sample was taken from 5 students' recount texts of the eight grade students of MTs Al-Amin Ngetos, Nganjuk. The researcher analyzed the students' recount texts based on the writing aspect that should be considered by the students in writing a recount text they are content, organization, grammar, vocabulary, and mechanics. The results showed that there were some mistakes made by the students, mostly their mistakes were inappropriate used of grammar and mechanics. So, the researcher provided suggestions for the teacher to help the students to know the writing aspects and learn how to apply them in writing text.
\end{abstract}

Keywords: writing, recount text, case study.

\begin{abstract}
Abstrak
Penelitian ini dilakukan untuk menganalisis kesalahan siswa dalam menulis teks recount. Subjek penelitian ini adalah siswa kelas VIII MTs Al-Amin Ngetos, Nganjuk yang berjumlah 38 siswa. Peneliti perlu menganalisis kesalahan siswa dalam menulis teks recount karena menulis adalah salah satu dari empat keterampilan penting untuk menguasai bahasa Inggris. Dalam pembelajaran bahasa Inggris di sekolah siswa juga belajar bagaimana menulis teks dan menyusun idenya menjadi teks yang tepat. Dalam memperoleh data, peneliti menerapkan penelitian evaluasi kelas dengan menggunakan teknik purposive sampling dimana sampel diambil dari 5 teks recount siswa kelas VIII MTs Al-Amin Ngetos, Nganjuk. Peneliti menganalisis teks recount siswa berdasarkan aspek menulis yang harus diperhatikan oleh siswa dalam menulis teks recount yaitu isi, pengorganisasian, tata bahasa, kosa kata, dan mekanika. Hasil penelitian menunjukkan bahwa terdapat beberapa kesalahan yang dilakukan oleh siswa, sebagian besar kesalahan mereka adalah penggunaan tata bahasa dan mekanika yang kurang tepat. Untuk itu, peneliti memberikan saran kepada guru untuk membantu siswa mengetahui aspek-aspek menulis dan mempelajarinya dalam penerapannya dalam teks tertulis.
\end{abstract}

Kata Kunci: writing, teks recount, studi kasus

\section{Introduction}

Writing is one of the four English skills that should be mastered by those who want to learn English. Writing is an ability of transmitting idea to a written text in order to inform the idea or information to the readers. In learning English, writing is also a crucial skill for the students to share what they think about a particular object then elaborate it into a good text. Hutchinson (2005: 5) explained that writing is a form of expression by writing word on a paper based on the people's thought which constructed using grammatical structure. In addition, he also stated that as the one of four English skill, writing is able to be developed by some practices which should be done regularly. But, in developing process of writing skill, it needs some efforts both form the students and the teacher. Writing is not as simple 
as what the theory stated because in fact, in conducting a writing activity the are many problems faced by the students. In line with this statement, Murcia (2000: 261) mentioned that writing is the most difficult skill to be learnt because it needs better productive language control than the other skills like listening, speaking, and reading. It means that when students want to master writing skill, they need to know the writing aspects and also be able to apply them in a text.

In fact, the eighthgrade students of Mts Al-Amin Ngetos, Nganjuk still have some problems in writing a text especially in writing a recount text. The students are incapable to make a good writing because of having lack of vocabulary mastery, getting difficulties in generating their idea, poor grammar, and so on. Vocabulary mastery plays a crucial role in conducting a writing practice because it is base element of language to express ideas. It can be assumed if the students had low vocabulary mastery so they would have difficulties in expressing their idea through the text. When the students apply inappropriate vocabulary in expressing their idea, there would be a confusion and miss understood about the information they want to deliver to the readers. It seems similar with the students' ability of developing and organizing idea in their text. Having low ability of developing and organizing ideas affect the quality of the students' writing. The ability of developing and organizing idea is the ability of stating the idea clearly in the text. In addition, students need to be able to provide a logical sequence of the idea to make the reader got the idea clearly. But in fact, Students have problems dealing with the way of organizing logical sequence because they cannot develop their idea and arrange the idea into appropriate sentences. Those problems made the students' written text provide blunder information and idea so it would be little bit difficult to be understood.

Making mistakes in producing writing is a common problem which made by those who are in learning process. Making mistakes in writing text will help the students to build their awareness to learn more in mastering the writing aspects in order to have better writing text. This motivates the researcher to conduct a research to analyze the students mistakes in writing recount text. This aims to know what actually the students' problems in writing a recount text and analyze the students text quality.

Brown (2004: 218) stated that writing is primarily a convention for recording speech and for reinforcing grammatical and lexical features of the language. According to Bell and Burnaby in Nunan (1989: 36), writing is an extremely complex cognitive activity in which the writer is required to demonstrate control of number variables. In arranging a sentence, the variables include control of content, format, sentence structure, vocabulary, punctuation, spelling, and letter formative. Beyond the sentence, the writer must be able to structure and integrate information into cohesive and coherent paragraph and text. Linse (2005) also stated that writing is a productive skill because in writing activity there is a process of producing information through e text then delivered to the reader. Nunan (2003: 88) stated that writing is the physical act of committing words or ideas to some medium, whether it is hieroglyphics inked onto parchment or an e-mail message typed into a computer. On the other hand, writing is the mental work of inventing ideas, thinking about how to express them, and organizing them into statements and paragraphs that will be clear to a reader (Nunan, 2003). In most languages, writing is a complement 
to speech or spoken language. Within a language system, writing relies on many of the same structures as speech, such as vocabulary, grammar, and semantic, with the added dependency on a system of sign or symbols, usually in the form of a normal alphabet. Nunan (2003)also mentioned that writing is a complex activity since it requires the learner's comprehensive abilities such as mastering grammar, vocabulary, and punctuation.

In the other words, writing can be defined as the activity of transforming idea into written language to share information, messages, and the writer's thought as a form of communication between writer and reader. But in writing activity, there are some aspect which should be mastered by the writer such as mastering vocabulary, grammar, and punctuation.

Kane (2000: 13-15) said that there are three rules in writing: grammar, the rules which structure the language; usage, concerning how we should use the language in certain situations; mechanics, conventions of writing require that a sentence begins with a capital letter and end with full-stop, punctuation (period, question mark, or exclamation point and so on).

Bratcher and Ryan (2004: 19) said that writing takes into account context, content, structure, and mechanics, as well as process. Broad (2003: 6) stated that writing consists of ideas: relevance, clarity, quantity, development, persuasiveness; form: organization and analysis; Flavor: style, interest, sincerity; mechanics: specific errors in punctuation, grammar, etc.; wording: choice and arrangement of words. According to Hegarty (2000: 5), writing involves remembering the sequence of sounds, the shapes of the letters, vocabulary, grammatical structures, and punctuation.
Jacobs, as cited in Weigle (2002: 114) mentioned that there are five aspects of writing: content, organization, vocabulary, language use, and mechanics.

Based on the explanations about writing aspect above, it can be constructed that the writing aspects consists of content, organization, grammar, vocabulary, and mechanics. So, in analyzing the students' recount text, the researcher uses the writing aspects above as the indicators to find the students writing mistakes. The researcher uses the writing aspects as the indicator in analyzing the students' mistakes in writing recount text because there are some previous researches which also analyzed the students' mistakes in producing recount text but they used different indicators. Rohmana \& L.S Jianggimahastu (2019) conducted a research about error analysis of students' recount text writing. They used students' recount text to be analyzed to find the common errors made by the students. But in this research, they just focus to the grammatical structure, word choice, and interlanguage interference. There is no analaysis about how the students understand the topic of the tetx and how to deliver the idea into the text. The another research was conducted by Andansari et al (2019) which focused their analysis on the grammar errors. So that is why the researcher of this research tries to analyse the writing mistakes made by the students based on five writing aspects which are determined from some resources.

\section{Research Methodology}

This research is a qualitative research with case study design because the data used in this research is not numerical data but the research used a descriptive data. The researcher used case study design to find mistakes made by the students in 
writing recount text. The researcher selected the eighth-grade students of Mts Al-Amin Ngetos as the subject in this research because there were found some problems in students' writing skill. The data which used in this research was got from the recount texts written by the students. The researcher applied class evaluation research using purposive sampling technique to choose the sample. Class evaluation research used to evaluate students' writing recount text and find the mistakes made by students. There were 5 recount texts written by 5 students of eighth-grade students of Mts Al-Amin Ngetos, Nganjuk. In collecting the data, the researcher used the students' writing recount texts to be analyzed to find students' mistakes in writing a recount text about embarrassing moment they have ever got which should consists of 3 paragraph individuallyband 250 words at least in 60 minutes. The text that would be analyzed was chosen based on the students' achievement in producing recount text.

\section{Result and Discussion}

The text written by the students were analyzed by the researcher in order to identify the mistakes of applying writing aspect; content, organization, vocabulary, grammar, and mechanics. In analyzing the content, the researcher identified the students' ability in generating ideas and providing supporting details. The researcher also needed to identify the students' ability in organize the text and build a logical sequence and cohesive. To know the students' grammatical ability, the researcher assessed the use of past tense which used in telling past events, agreement, word order, articles, pronouns, and prepositions. The use of vocabulary was also crucial in constructing a recount text so the researcher analyzed the word used in the text made by the students. Then mechanics should be analyzed to know the students' quality of applying correct spelling, punctuation, and capitalization. Below are the research findings based on what the researcher found in students' recount text:

\section{Content}

In content aspect, the researcher focused on how the students generate the ideas and state the supporting details. Generating ideas is crucial in starting to develop the idea. This idea will determine how the writer deliver the additional information to support the idea, it is called as supporting details. Galbraith (2009: 50) explain that generating ideas is a process transmitting information from the students' memory to be written in a text which be delivered to the reader. Based on the analysis to the students' writing of recount text, there were the findings as follow:

Most of the students got confused in writing the idea in the beginning. The researcher provided "embarrassing moment" as the topic to write a recount text, but they had difficulty in understanding what should they write about embarrassing moment. Understanding topic is crucial for the students because when they know what will be written will help the students to elaborate the main idea and supporting details. In expressing main idea students could not put the main point of the paragraph. They just wrote what they wanted to express based on their experience but they did not consider about giving main idea as the center of the text. In stating main idea in every paragraph, the students just separated every paragraph based on what they want ed not the idea or they thought about how long the paragraph should be. This is the students writing in splitting paragraph: 
"After that, I arrived in class, I am very happy to see my friend again after not seeing each other for a long time. Then I talked to my friends, each of us told a story about their school holidays.

We also laughed together because we listened to each other's stories., and we feel good to be back in school, and to see each other."

From the sample of the students' writing recount above, it can be seen the students had low awareness arranging main idea for each paragraph. The first sentence in second paragraph shows that the students could not develop main idea for the second paragraph. The information from the second paragraph are still support the idea from the first paragraph. In other words, the students should build a new main idea to develop in second paragraph and make some supporting details to support the main idea.

The next finding is the students getting difficulties in providing supporting details. Supporting detail is important in writing a text as the additional information given by the writer. The students need to arrange appropriate supporting details which are related to the main idea. Based on the students' writing, most of them could not put a clear main idea so it relates to the students' attitude of delivering supporting details. The mistake made by the students can be seen as follow:

"At that time, $\mathrm{i}$ accustomed be having a recreation in Jogja, my friends which i were having fun buying souvenirs in Malioboro. we tend to tend to scattered places to hunt out the souvenirs we might like. because of the huge vary of people among the Malioboro Market, we tend to tend to lose track of each different. At that time I and my a combine of friends rush to hunt out another one, as a results of it had been nearly evening and additionally the bus was waiting to travel home."

From the finding above, it can be seen that the students were getting confused in developing supporting details related to the main idea. The paragraph is taken from the first paragraph of the students' recount text which provide main idea clearly at the first sentence that the student having holiday in Jogjakarta. After that as the supporting details, the student explained about his friend who made a jumping idea from telling about the writer to the other people. In this paragraph, the student needed to explain the main idea smoothly by developing supporting details.

\section{Organization}

Organization is how clear the students state the idea and how they adding information to support their idea in the tex. Besides, organization also deals with the logical sequence and cohesive of the text (Ekorini, 2015: 18). By analyzing the students' recount text, the researcher found some mistakes made by the students in delivering their recount text.

The students having problem in stating idea and additional information to support the idea. It is similar and related to the problem number 1 because the both are about the students' ability in understanding and presenting main idea and supporting details. Most of the students need more understanding what topic they want to write. The topic of "embarrassing moment" made the students tried to understand how to deliver their experience which contained an embarrassing moment. In delivering the idea, they explain using messy sentence as follows:

"My step was nearly preparing to him, I referred to as his name but he did not gyrate." 
Based on the student's sentence above, it can be seen that actually the student wants to tell that he saw people who look alike his friend. Then he tries to call his friend's name but his friend does not turn his head. This information which want to tell to the reader but the student cannot state the idea clearly so the reader getting difficulty in understanding the text.

Logical sequence is needed in writing a text to help the reader follow the development of the idea provided by the writer. Oshima \& Hogue (1999) explains that logical sequence uses particular words to sign a transition and to show the relationship between the ideas. In writing recount text, the students have told the text in logical order, but they have less awareness of using the chronological order to show the relation between one idea to the others like the sentence below:

"Well, when I came home I talked so much that I forgot the time and forgot to put my motorbike key at that time I put it in my bag but when I was about to go home I was confused looking for where my motorbike key was after looking and was getting more panicked because it was getting late afternoon afraid that I would walk it was dark coming home because it passed through the forest far from the village with minimal lighting."

From the sentence above, it can be found that the student did not apply the chronological order to build a logical sentence of the text. The student put some clauses in one sentence which actually it should be separated into some sentences and add the chronological order to make a sense of the sentence.

\section{Vocabulary}

Vocabulary mastery is crucial for those who want to learn about certain language, including English. Vocabulary is the basic component to know in learning English because in it is used to understanding the information expressed in English. Renandya and Richards (2002: 225) explained that vocabulary is core component in language proficiency and it determine how the students master listening, speaking, reading, and writing. From the analysis done by the researcher to the students' recount text, there are some findings related to the students' mistake in vocabulary use in their recount text.

The students used inappropriate vocabulary to tell information in recount text. This problem is found almost in all the students' writing that were analyzed by the researcher. Most of them used the word which are just translated from Indonesian language. Here are some mistakes samples made by the students:

"I hurriedly began to approach him and shouted for him"

"At that time I and my a combine of friends rush to hunt out another one, as a results of it had been nearly evening and additionally the bus was waiting to travel home."

From the mistakes which made by the students in applying vocabulary to their recount text, it can be analyzed that the students need more contextualized practice to know how to use an appropriate word. In first sentence the phrase "shouted for" should be used in shouting for something like "I shouted for help but nobody came" which means that someone need a help. It becomes different from the first sentence which tells that the writer shout to the people who he thought was his friend. In this context, the students get confused about what the appropriate phrase should be 
used to express the sentence. It also happens to the second sentence where the students used the word "combine" to express a group of his friends. In this sentence actually the student can use "friends" to express plural form. Besides, the use of the "travel home" which is the student wants to state about going home.

\section{Grammar}

Grammar in English is important to arrange the sentence and make it have sense. Grammar deals with effective complex construction, correct agreement, tense, number, word order/function, articles, pronouns, prepositions. In analyzing the students' recount text, it is found many mistakes in applying grammar in the sentences. The most mistake made by the students is applying agreement. The students are still confused in using past tense as the basic tense used in recount text. Here some mistakes made by the students in writing recount text related to the agreement:

"At that time I and my a combine of friends rush to hunt out another one as a results of it had been nearly evening and additionally the bus was waiting to travel home"

The underlined word shows that there is a mistake of agreement which the word "rush" as verb should be in past form "rushed".

"Really, that incident terribly embarrassed and needed to continue happy, as did my friends."

In this sentence there is something missing which so crucial in constructing sentences, it is the verb of "was". The verb should be added after the subject of "really, that incident was terribly embarrassed". This mistake is usually made by the students in writing recount text because they think that they write a text which use present tense. In additional, the students cannot identify the function of the word they use in the sentence. Like in the sentence of "I want to tell you about my embarrassing moment that moment happened when I am senior high school". The phrase of "senior high school" refers to the grade of education, it does not refer to the human being. But in this sentence the phrase of "senior high school" is non-human noun. So, the students should be able to differ both of them and put a preposition "in" like the sentence below:

"I was in senior high school" or "I was senior high school student".

\section{Mechanics}

Mechanic is writing aspect which contains about demonstrating correct spelling, punctuation, and capitalization. Mechanic is important in written communication because in it needs to build readers' perception through the punctuation to know the writers' intention. Punctuation is like a direction for the readers to understand what the writers want to express (Awad, 2012: 221). It seems so simple but there are many people having low awareness of applying appropriate mechanics in their text. The students of eighth-grade of MTs Al-Amin, Ngetos, Nganjuk also have some mistakes in applying mechanics in writing recount text. Most of the students have good spelling in writing the words. They also have less mistakes to write the words in English because they have checked what words they will used in dictionary. In the other hand, they have made some mistakes of applying punctuation and capitalization.

The use of punctuation to give marks of the sentences to know the intention of the writers. Punctuation is also used to make sense, clarity and stress the sentences. There are some mistakes in applying 
punctuations found by the researcher from the students' recount text:

At that time, i accustomed be having a recreation in Jogja, my friends which i were having fun buying souvenirs in Malioboro. we tend to tend to scattered places to hunt out the souvenirs we might like. because of the huge vary of people among the Malioboro Market, we tend to tend to lose track of each different.

From the students' text above it can be seen that there are some mistakes made by the students when using capital letter. The underlined words show how low the students' awareness of the use of capital letter. It is simple for the students and the teacher to identify the use of capital letter because capital letter is also applied in Indonesian writing. The sample shows the word " $i$ " which should be stated in capital letter. The word " $i$ " implies noun which refers to the first people who tells the statements. For the addition, there are also students who uses inappropriate capital letter. They stated word which actually do not need to be capitalized but they write it using capital letter like follow:

Finally, the ceremony started, My friends and I carefully listened to the speech of the principal.

The word "my" is the possessive noun which there is no special rule to write it using capital letter except in the first sentence. But in this sentence, the student uses capital letter even it is stated in middle of the sentence. There must be misunderstanding about what kind of words should be capitalized in writing sentences. Besides, the students also have made mistakes in applying punctuation. Full stop and comma are the most used punctuation which are applied by the students, but in the other hand they also have less understanding about how to put both of the punctuations.

We also laughed together because we listened to each other's stories. , and we feel good to be back in school, and to see each other.

The students put comma and full stop in one place which indicates double meaning and ambiguity. The student uses too many words of "and" which actually can be replaced by the use of comma. Based on the context of the sentence above, the student wants to state three main information which actually it can be separated into two different sentences to provide effective sentences.

Writing is an activity which needs more effort to be learnt by the students especially for EFL students. Based on the research findings, the researcher summarizes some problems faced by the eight-grade students of MTs Al-Amin Ngetos, Nganjuk in writing recount. The first problem is they get confused in generating idea from the topic. Having a good understanding of the topic is important for the students who want to write a text because they will express what they thought about the topic through the text. However, in writing a recount text, some students still confused to analyze the topic. They made mistakes in generating the idea through the text. They could not put a main idea then followed by some supporting details. The students also could not consider about the importance of a cohesive among the sentences of their texts. Some of the students delivered different topics in one paragraph. One the problem which caused the students' mistake in generating idea is they did not do prewriting activity. In doing observation to the teaching and learning process of writing skill, the teacher just explained to the students about recount text then 
delivering the example of recount text. After getting the materials, the teacher asked the students to write a recount text with topic of "embarrassing moment". The teacher did not direct the students to do pre-writing. Pre-writing is needed to direct the students to do a brain storming about the topic. It aims to facilitate them to generate the idea and start to write based on the topic (Alemu, 2020: 46).

The students also have problems of mastery vocabulary. The students need more exercises of vocabulary use. Most of the students used inappropriate vocabulary because they did not understand the context. In fact, the students used dictionary to help them find some vocabularies to be applied in their recount text. But the problem is the teacher did not control the students' activity in applying vocabularies to their recount text. In addition, the students have low practices in using vocabulary or doing practice to make their writing better. Both the students and the teacher should aware that mastering vocabulary in learning language, especially as foreign language, is crucial. Hasan and Subekti (2017: 59) explain that the students' mastery of vocabulary has correlation with the students' writing skill. For the students who have good mastery of vocabulary will be good in writing activity.

Another problems faced by the students in writing recount text are grammar and mechanics. There are some mistakes made by the students in applying grammar in their recount texts. Actually, the teacher had explained about the grammatical features used in recount text but the students have low practices in arranging sentences using appropriate grammatical structure. Most of the students did not aware that they should use paste form in expressing past event. In some sentences they used past form but in other sentences they used present or future form. The inconsistent of the grammar used can be reduced by doing more practices. The teacher needs to direct the students to aware about the use of grammatical structure. It also happens to the students when they apply mechanics in their writing. This aspect is the most ignored aspect in writing because most of the students, including the teacher, have low awareness of applying mechanics. The eight-grade students of Mts Al-Amin Ngetos, Nganjuk do not have any materials about mechanics like applying punctuation and capital letter before they have writing practice. It affects their writing quality because when they have practice by hand writing, it can be found so many mistakes of capital letter use and punctuation.

\section{Conclusion}

This research is a case study which concerns to analyze the students' mistakes in writing a recount text. The researcher analyzed the students' texts based on the writing aspects, namely content, organization, grammar, and mechanics. The findings show that there were many mistakes made by the students in writing a recount text. Further, the students had low awareness and understanding about the writing aspect. The teacher also did not explain about how to conduct a good writing through practice, yet they just explained what recount text is based on the text book they used at school. One that the students need to improve their writing skill is having more practice which will help them to have better understanding about writing aspects.

\section{Acknowledgement}

For all the students of MTs Ngetos, Nganjuk, The Headmaster, and my family. 


\section{References}

Andansari et.al. (2019). The Students' Error Analysis of Writing in Recount Text for the Minineal Students. Proceedings of $1^{\text {st }}$ STEEM. Retrieved from http://seminar.uad.ac.id/index.php/ STEEEM/article/view/3304/804.

Alemu, M. (2020). The Role of PreWriting Strategies to Enhance the Students' Idea Generating Abilities: The Case of First-Year Computer Science Students of Haramaya University. International Journal of Education \& Literacy Studies. 8 (1): 40-47.

Awad, A. (2012). The Most Common Punctuation Errors Made by the English and the TEFL Majors at An-Najah National University. An - Najah Univ. J. Res. (Humanities). 26 (1): 211-233.

Bratcher, S \& Ryan, L. (2004). Evaluating Children's Writing, A Hanbook of Grading Choices for Classroom Teachers: Second Edition. New Jersey: Lawrence Erlbaum Associates, Inc.

Broad, B. (2003). What We Really Value, Beyond Rubrics in Teaching and Assessing Writing. Utah: Utah State University Press.

Brown, H. D. (2004). Language Asessment: Principles and Classroom Practices. New York: Pearson Education, Inc.

Ekorini, P. Z. (2015). Using Comic Strips: Building Students' Writing Viewed from Intelligence. Thesis, Sebelas Maret University.

Galbraith, D. (2009). Writing About What We Know: Generating Ideas in Writing. Retrieved from (PDF)
Writing about what we know: Generating ideas in writing (researchgate.net), 27 November 2020.

Hasan \& Subekti, N B. (2017). The Correlation Between Vocabulary Mastery and Writing Skill of Secondary School Students. Journal of English Language and Language Teaching. 1 (2): 55-60.

Hegarty, C. (2000). Writing; English in Context. United States of America: Saddleback Education Publishing.

Kane, T. S. (2000). The Oxford Essential Guide to Writing. New York: Barkley Books.

Murcia, Celce, Marianne, \& Elite. (2000). Discourse and Context in Language Teaching. Newyork: Cambridge University Press.

Nunan, D. (1989). Designing task for the communicative classroom. Cambridge: Cambridge University Press.

Nunan, David. (2003). Practical English language Teaching ( $\left.1^{\text {st }} e d.\right)$. New York: Longman.

Oshima, A. \& Hogue, H. (1999). Writing Academic English ( $3^{\text {rd }}$ ed). NY: Pearson Education.

Renandya, W.A. \& Richards, J.C. (2002). Methodology in Language Teaching. New York: Cambridge University Press.

Rohmana, W. I. M. \& L.S, Puput Jianggimahastu. (2019). Error Analysis on Students' Recount Text Writing-Junior High School Students. Journal of English Language Teaching and Learning. 1 (1): 10-16.

Weigle, S. C. (2002). Assessing Writing. Cambridge: Cambridge University Press. 